\title{
Prospects and Challenges of Postharvest Storage and Losses of Potato (Solanum tuberosum L.) in Central highlands of Ethiopia: A Review
}

\author{
Abebe Chind Degebasa \\ Ethiopian Institute of Agricultural Research/EIAR/, Holetta Agricultural Research Center, Horticulture Research \\ Division, P.O.Box 2003, Addis Ababa, Ethiopia
}

\begin{abstract}
In Ethiopia, potato is becoming a prominent source of income since the crop is the most important cash crop for smallholder farmers in the mid-altitude and highland areas of the country. Post-harvest management in potato crop is a set of operations and functions between crop production and consumption. Potato is inherently perishable. During the process of harvesting, storage, distribution and marketing, substantial losses are incurred which range from a slight loss of quality to substantial spoilage. Post-harvest losses may occur at any point in the marketing process, from the initial harvest through assembly and distribution to the consumer. The causes of losses are many: physical damage during handling and transport, physiological decay, water loss, or sometimes simply because there is a surplus in the marketplace and potatoes are kept longer under inconvenient condition for some time. The tuber, once harvested, is susceptible to environmental influences and requires proper handling and processing in to value added products that have longer shelf-life. The increasing market demand for quality is requiring growers and others engaged in the industry to strictly follow appropriate principles and standards to ensure higher productivity and quality with reduced losses and minimum cost all along the potato value chain. There is a huge estimate of post-harvest losses for fruits, vegetables, roots and tuber crops that sometimes reaches as high as $50 \%$. So far there are limited marketing options for the individual farmer in the major production regions and there are almost no storage facilities to help producers stabilize the low price during peak production. From the estimated potato acreage of over $0.3 \mathrm{~m}$ ha, a total of 3.65 million tons of potatoes is produced annually. About $20-25 \%$ of the annual production is a post harvest loss. In Ethiopia most of the potato produced is mainly consumed as boiled, salad and stew preparations. Potato is consumed throughout the year, but with higher consumption during harvesting. Use of alternative recipes like crisps, french fries, flakes, pre-peeled potatoes and various snack food items has not developed well. This in combination with the high post-harvest losses is believed to have limited the overall consumption of potato in the country to be one of the lowest for per capital consumption in Africa.
\end{abstract}

Keywords: Postharvest, Farmers Field School, Farmer Research Group, potato storage

DOI: $10.7176 / \mathrm{JNSR} / 10-5-04$

Publication date:March $31^{\text {st }} 2020$

\section{INTRODUCTION}

Potato (Solanum tuberosum L.) ranked as the third most important food crop following rice and wheat and is consumed by over a billion people throughout the world (Devaux et al., 2014). Potato promises higher calorie per unit area production potential than any grain and can be produced, stored, and consumed without major technological inputs. Potato is considered as highly nutritious. Recent trends indicate that potato production in densely populated developing nations is on the rise (Bradeen and Haynes, 2011). According to Devaux et al., (2014), half of the total production occurs in developing countries that makes potato the third most important food crop globally (FAO, 2013). Lutaladio and Castaldi (2009) suggested that the high yield potential of potato per hectare of arable land, good nutritive value, and cooking versatility have resulted in a threefold per capita potato consumption in the developing world, from $6 \mathrm{~kg}_{\text {capita- }}{ }^{1}$ year- ${ }^{1}$ in 1969 to $18 \mathrm{~kg} \mathrm{capita}^{-}{ }^{1}$ year- ${ }^{1}$ in 2009 . The crop's short cropping cycle allows it to serve as a hunger-breaking crop, and makes it suitable for intercropping and double cropping, especially in cereal-based production systems in Africa and Asia (Cromme et al., 2010; Gebremedhin et al., 2013).

Gildemacher et al., (2009), reported that potato is a source of food and cash income, playing an important role in the rural livelihood system of the densely populated highlands of sub-Saharan Africa. Ethiopia is one of the major potato producing countries in Africa as $70 \%$ of its arable lands in the highlands are suitable for potato production. Potato being cultivated for more than 150 years in Ethiopia, it grows dominantly in the Northern Central and Eastern highlands of the country (Gildemacher et al., 2009) and the recent reports of CSA, (2015/16) stated that its production area has reached about 0.3 million ha producing more than 3.66 million tons in both Meher and Belg seasons. However, potato yields are relatively low in developing countries and a number of yield limiting factors are listed by many researchers throughout the glob among which diseases and pests are considered a major cause of low productivity.

Gebremedhin et al.(2008) described that, the major bottlenecks to higher potato yield and reliable supplies in 
Africa are limited or no access of farmers to high quality seed tubers of improved varieties, poor crop husbandry practices (e.g. disease and soil fertility management), and poor post-harvest management. A promising alternative to traditional clonal propagation of tetraploid potatoes is the production of hybrid true potato seeds: planting 10 hectares, for instance, takes just 200 grams of easily transported true seeds, compared with 20 tons of perishable seed-tubers. It was introduced in Africa at the end of the $17^{\text {th }}$ century by Christian missionaries through the formation of small plantations. Soon after, potatoes quickly became part of the feeding habits of both rural and urban populations. As in Europe, potato production could contribute in the fight against food insecurity in the subSaharan African countries.

The general constraint of potato production in Ethiopia includes poor quality seed, poor crop husbandry, poor post harvest handling and marketing systems. In agriculture sector, a lot of emphasis has been put on research and development of agriculture production and fewer resources in post harvest development. Potato is a bulky and fleshy crop with a short storage life therefore needs careful handling, packaging and storage. According to Hirpa et al. (2010) in Ethiopia potato tubers are harvested, stored, packaged and transported with little care to prevent physical damage to the tuber, most likely because of the low level of knowledge about the consequence of physical damage by all parties involved. The tools used by farmers to dig out tubers from the soil might not be appropriate (too sharp or elongated ending). Physical damage in seed tubers may also occur during storage because of piling of one sack upon the other and lack of ventilation. Potatoes are usually packed in sacks which cannot protect tubers from any external pressure causing bruising and stabbing. Potato sacks are usually transported by pack animals and are tied by ropes on their back, which may cause bruising to tubers. Distant transportation takes place by lorries. In this case loading and unloading is done by throwing up and down the tuber sacks. The tubers may be loaded with other sharp or beneath heavy materials which might cause damage to the tubers.

In Ethiopia, post-harvest losses of horticultural crops may be estimated for about 15 to $70 \%$ at various stages. Potato is known as a semi-perishable commodity and storage of both seed and ware potatoes which is problematic for most farmers, as storage losses can reach 50\% and sometimes higher (Borgel, 1980). These losses could be occurred during harvesting, sorting, cleaning, handling and packing, transportation, storage, distribution or marketing and processing. Hence, improving food security requires a comprehensive approach towards post harvest managements using new strategies and/or technologies to ensure the higher-value of post-harvest produces. The percentage loss of potato due to post harvest handling is estimated to be $20-25 \%$ (Benyam et al., 2018). Potato production is seasonal and it lack proper storage methods such as cold storage.

\section{Major Potato Post-harvest Losses}

In the absence of storage technologies for ware and seed potato, farmers keep potato harvest in the ground for a long period in Ethiopia. This reduces tuber yield significantly. A study on extended harvesting period in Alemaya revealed that yield of marketable tubers was reduced by $60 \%$ when tubers were harvested at 210 days after planting as compared to a harvest at 120 days (Berga, 1994). Similarly, Gebremedhin et al., (2001) reported significant yield reductions (70-100\%) when harvesting was delayed from about 125 days to 230 days after planting. Estimates of the production losses in developing countries are hard to judge; but some estimate the losses of potatoes, sweet potatoes, plantain, tomatoes, bananas and citrus to be very high. About $20-25 \%$ of the total produce (7.2 million tons) is lost after harvest. Globally (Benyam et al., 2018), horticultural crops postharvest losses have been reported at 19\% for the USA at an estimated annual loss of $\$ 18$ billion (Kantor et al., 1997). Higher losses have been reported for African countries ranging between $15 \%-30 \%$ of the harvested product (Buys and Nortje, 1997).

Post-harvest losses are mainly caused by different physical, environmental and biological factors which include mechanical injuries, extreme temperatures and pathogens (Clark et al., 2004). The causal factors enhance post-harvest losses through changes in the chemical composition and physical properties of the tuber in the process of respiration, loss of moisture from the tuber, sprouting, and spread of diseases. In the light of the little information generated on the major factors of post-harvest losses in Ethiopia, some of the principles in post-harvest management and the basic environmental and physiological causes of post-harvest loss are discussed as below.

\section{Physical, biochemical and physiological losses}

Physical losses include the various responses of tuber to excessive or insufficient heat, cold, or humidity. Proper storage is required to allow ventilation and heat exchange to maintain proper temperature level, to reduce the air and gas exchange (oxygen, carbon dioxide, and ethylene) and to minimize water loss. Losses caused by mechanical injury are usually overlooked. Physical injury is a loss by itself, and it can result in secondary physiological and pathological losses. Mechanical injury can occur at hilling, harvesting, and handling operations such as grading, transporting and marketing.

Heavy clouds and angular and pointed stones increase damage levels. Among tubers from the same cultivar, the degree of damage is influenced by the dry matter content and turgidity of the tubers. High dry matter content causes higher braising. Good level of care is needed during harvesting and handling operations to minimize damage caused on tubers. The damaged tuber always has a shorter post-harvest life than the undamaged tubers. 


\section{Respiration}

Potato tubers respires using sugars converted from starch. Therefore, respiration reduces the starch content of the tuber. During respiration, the tubers use oxygen from the air and produces water, and carbon dioxide and heat. The most important effect of tuber respiration is the production of heat and its subsequent effect on storage temperatures and the action required to control it. If the respiratory heat is not removed, the temperature of the potatoes rises by $0.25^{\circ} \mathrm{C}$ per 24 hours. The rate of respiration is dependent on the temperature and is minimum at about $5^{\circ} \mathrm{C}$. Tubers that are stored at relatively higher temperature lose their moisture after some time and become unfit for consumption or for prolonged storage as seed for the coming season planting. The problem was observed in seed potatoes stored in diffused light store (DLS) at Shashemene area. Fresh weight of tubers is considerably reduced in storage both due to respiration and water loss. It was observed that mean tuber weight loss as high as $23 \%$ was recorded when potatoes were stored in naturally ventilated storage for 120 days (Table 1). The tubers were dry due to excessive moisture loss and they were not suitable for planting after 6 months. This was due to relatively higher temperatures and dry air that enhances respiration and consequently desiccates the stored tuber.

Table 1. Mean weight loss of tubers of four cultivars stored in naturally ventilated ware storage

\begin{tabular}{lcc}
\hline $\begin{array}{l}\text { Days in store } \\
\text { after harvest }\end{array}$ & $\begin{array}{l}\text { Mean fresh } \\
\text { weight loss } \mathbf{( g / k g})\end{array}$ & $\begin{array}{l}\text { \% loss on fresh } \\
\text { weight bases }\end{array}$ \\
\hline 30 & 33.5 & 3.4 \\
60 & 133.2 & 13.3 \\
90 & 183.5 & 18.3 \\
120 & 233.7 & 23.4 \\
\hline
\end{tabular}

\section{Loss of moisture}

Water is lost from tubers by evaporation. The rate of loss of water is highly affected by the weather condition of the location and it is proportional to the water vapour pressure deficit, i.e. the drying power of the surrounding air. The potato will lose moisture rapidly if it is immature, wounded and unhealed and sprouted. Immature tuber loses water more rapidly because of its more permeable skin and increase in water loss when sprouting starts because the surface of sprouts is more permeable to water vapour.

Loss in dry matter content

Tuber respiration during storage results in dry matter losses. This amounts to $1-2 \%$ of fresh weight in the first month and about $0.8 \%$ per month thereafter until sprouting is well advanced when dry matter loss will amount to $1.5 \%$ per month. Temperature and humidity of storage have an effect on the dry mater in relation to the water content and changes in specific gravity of the tubers. Potatoes stored at relative humidity of $83-84 \%$ show increase in specific gravity during storage at both 4.4 and $12.8^{\circ} \mathrm{C}$. At $90 \%$ relative humidity, however, the specific gravity of tubers remain practically unchanged in storage up to 6.5 months at $4.4^{\circ} \mathrm{C}$ and $10^{\circ} \mathrm{C}$ (Smith, 1987). Similar result was obtained in ventilated ware storage with internal temperature for 120 days ranging between 3.6 and $7.8^{\circ} \mathrm{C}$ and relative humidity of $86.6-87.0 \%$ at Holetta (Table 2). Nevertheless, respiration, sprouting, loss of moisture from the tuber and pathogenic losses have mostly a direct influence on the dray matter content and thus on the use or processing quality of the tuber (Elazar, 2004).

Table 2. Change in specific gravity after 120 days in naturally ventilated ware potato storage at Holetta

\begin{tabular}{lllllll}
\hline & \multicolumn{7}{c}{ Potato Varieties } \\
\cline { 2 - 7 } Days in ventilated ware store Jalenie & Tolcha & Zengena & Menagesha & Gorebella & Mean \\
\hline 0 & 1.095 & 1.098 & 1.090 & 1.071 & 1.090 & 1.090 \\
45 & 1.096 & 1.103 & 1.102 & 1.071 & 1.088 & 1.092 \\
120 & 1.103 & 1.099 & 1.102 & 1.086 & 1.095 & 1.098 \\
Mean & 1.098 & 1.100 & 1.098 & 1.076 & 1.091 & 1.093
\end{tabular}

\section{Sprouting}

Generally, tubers are dormant at harvest. A very important point related to successful storage is an understanding of dormancy and sprouting. The tuber has a definite life cycle. Following field maturity, the tuber remains dormant for a specific period of time which varies with variety and the influence of the crop growing and storage conditions. Maturity at harvest time influences the degree of sprouting. Stresses at any of these stages reduce tuber natural dormancy. Damaged and diseased tubers sprout sooner than healthy ones. It has already been noted that once dormancy ends, sprout growth leads to increased respiration and moisture loss from the tuber via sprout tissue. The higher the temperature over a range of about $4{ }^{\circ} \mathrm{C}$ to $21{ }^{\circ} \mathrm{C}$, the shorter the dormancy period. The most critical temperatures are between $4{ }^{\circ} \mathrm{C}$ and to $10{ }^{\circ} \mathrm{C}$. However, it is possible that tubers stored first at low temperature followed by storage at $10{ }^{\circ} \mathrm{C}$, could have a shorter dormant period than following continuous storage at $100{ }^{\circ} \mathrm{C}$.

The number of sprouts per tuber, which determines the number of main stems per plant, is influenced by variety, tuber size and the degree of apical dominance. In a given variety, the degree of apical dominance is influenced by storage conditions, particularly temperature (Table 3). Sprouting directly affects quality of ware potato presumably due to its enhancing effect on water and respiratory loss. 


\section{Pathogenic Losses}

Post-harvest attack by microorganisms can cause a serious loss. Post-harvest diseases can start prior to harvesting in the field, at or following harvesting through wounds. Insects and rodents may cause additional pathogenic losses. The potato tuber moth causes the most serious damage in the store. The larval damage causes direct weight loss and the wounds lead to secondary infection by microorganisms. During storage, aphids can attack the young sprouts and shoots, and they can disseminate certain virus diseases, especially potato leaf roll virus (PLRV). Quantitative pathogenic losses result from the frequently rapid and extensive breakdown of tissue for example, fungal and bacterial attack which is followed by massive attack by secondary organisms. This mostly is the prime importance in storage and can cause substantial damage.

Table 3. Estimated storage life of ware and seed potato

\begin{tabular}{cccc}
\hline \multirow{2}{*}{$\begin{array}{c}\text { Storage } \\
\text { temperature }\left({ }^{\circ} \mathbf{C}\right)\end{array}$} & \multicolumn{3}{c}{ Storage life (no. of months) } \\
\cline { 2 - 4 } & Ware & \multicolumn{2}{c}{ Seed } \\
\cline { 2 - 4 } & Dark & Dark & Indirect light \\
\hline 4 & 10 & 10 & 11 \\
10 & 5 & 6 & 9 \\
15 & 4 & 5 & 8 \\
20 & 3 & 4 & 6 \\
25 & 2 & 3 & 5 \\
30 & 1.5 & 2 & 3 \\
35 & 1.0 & 1 & 2 \\
\hline
\end{tabular}

\section{Storage Methods \\ Traditional storages}

In Ethiopia potatoes are basically stored for two reasons: ware and seed. Farmers use different traditional potato storage system depending on the use. However, these storage facilities are not proper to keep the quality of tuber for more than 1-2 months. As a result, farmers are forced to sell their potatoes at low prices during harvest. They buy seed potatoes at a very high price at planting. Some farmers store seed potatoes either in burlap sacks or in dark rooms, which result in the formation of long and etiolated sprouts that break easily while handling and during planting. Storing seed potatoes in diffused light stores (DLS) results in the formation of shorter and sturdier sprouts than storing in the traditional dark storage method or in burlap sacks. Potato seeds stored in DLS have better emergence, more uniform growth and better plant establishment, resulting in higher tuber yield than seed stored in the traditional storage.

At Holetta, potatoes stored in burlap sack produced smaller sprouts and lost higher weight than those stored in either 2, 3 or 4 layers on shelves of DLS. Potatoes stored in multi-layered burlap sacks produced less number of sprouts per tuber. These results were confirmed by research carried out at Alemaya where storage of seed tubers in dark resulted in a higher weight loss than storage in DLS. Field (under ground) storage is commonly used in the highland area. Farmers leave their potatoes underground for prolonged use by piece-meal harvest which also helps regulate the low market price they often encounter at peak times and improve their use for consumption. This is the most common storage system of farmers both for ware and seed potatoes, but it is preferred most for ware due to high dry matter. It can keep up to 4 months in cool highlands. However, this extended method is challenged by untimely rainfall that hastens tuber rotting, tuber moth problems causing considerable yield loss, and tuber infectious diseases that degenerate the tubers. Floor storage (piling potatoes in the room on the floor) is used both for ware and seed purpose which helps to keep the potato up to 2-3 months in cooler areas. Storage on raised bed, locally called ko't or alga, is usually used to keep potatoes for seed. Storing potatoes in pit in which the wall is made from mud and roofed with straw is exercised to keep ware potato for 1-2 months.

All the methods used by farmers had considerable quantity and quality loss (Table 4) to ware and seed potatoes. Nearly all the major physical, physiological and disease problems that cause loss were not effectively controlled or regulated adequately. The problem is very critical in affecting seed quality and subsequent performance of the crop in the field. The seed quality is thus the most pressing factor in the potato enterprise. In general, farmers have no appropriate facility for package, transport, and storage. Thus, they cannot keep stock to reduce post-harvest loss and reduce price fluctuation in order to obtain better price. 
Table 4. Effect of extended harvest on yield of potato, average of three years Treatments (Days in ground after $1^{\text {st }}$ harvest) Percentage unmarketable tuber (3 years average) Harvest at maturity (control)

15

30

45

60

75

90

105
65.7

71.1

78.7

83.1

84.5

81.0

88.1

\section{Diffused light stores (DLS)}

Diffused light storage (DLS) is a storage method using a low cost rustic structure to store seed tubers. It maintains seed tuber quality by allowing diffusion of light and free ventilation which suppress sprout elongation and thereby slow-down aging of the sprout. In an experiment carried out in Holetta to quantify the effects of storage methods, Lemaga et al. (1994) found that seed tubers stored in multi-layered burlap sacks (similar to farmers' dark storage method) produced significantly taller sprouts and lost significantly more weight than those stored in DLS. This shows that DLS has a better potential to keep quality seed tubers than the traditional storage method. Even though the storage performance differs from variety to variety, seed potatoes can be stored in DLS up to 7 months without considerable depreciation of seed quality (Endale et al., 2008). The DLS is usually used for the storage of seed potatoes of improved varieties whereas the other storage mechanisms are used for the storage of seed potatoes of local varieties.

In the central and northwestern areas of Ethiopia only $5 \%$ of potato farmers were found to use DLS (Gildemacher et al., 2009b) but the use of DLS for seed tubers of improved varieties is becoming common in the central area of Ethiopia. About $87 \%$ of the farmers in the central area and $25 \%$ in the northwestern area were found to use DLS for storage of seed potatoes of improved varieties (Tesfaye et al., 2008). The use of DLS is slowly increasing in the northwest. In the eastern area of Ethiopia, the use of DLS is restricted to the cooperative community based seed enterprises established by the FAO seed security project (Mulatu et al., 2005a).

Seed potato storage is a common practice in all potato producing areas of Ethiopia. Farmers store seed potato by leaving the tubers in the soil un-harvested (postponed harvesting); by other traditional storage methods like in a local granary, on bed-like structures or the floor in their house; or by diffused-light storage (DLS). Because of storage and other postharvest problems Ethiopia loses $30-50 \%$ of its potato production (Endale et al., 2008). Types of storage are described in more detail below. The potato tuber which is to be used as seed has to be stored and prepared for planting so that it retains its vigor, remains healthy and in insect-free condition up to the time of planting. Although this can be done in costly refrigerated storage, the needs of the household and small-scale producer or enterprise demand a low-cost alternative technology. After complete growth of the potato crop in the field and before ready for planting, the tuber enters a period of rest known as dormancy.

During dormancy the tuber is relatively easy to store. However, once dormancy ends and sprouts growth commences, unless planting is done shortly after wards, sprouting must be controlled to protect the tuber from becoming exhausted, infecting with virus and damage by insect. Seed tuber storage must include, therefore, a way of controlling the growth of the sprouts and other pests. The diffused light storage is a very simple and low cost structure which allows the diffusion of daylight and free ventilation (air circulation) inside the storage that helps to suppress the elongation of sprouts as opposed to dark storage. It helps to maintain seed quality for a long time in areas where prolonged storage is a must. Observations made at Holetta indicated that tubers could be stored a long as 7 months without considerable depreciation of seed quality. The storage performance, however, was noted to vary depending on variety. According to the results, tuber weight loss, time of dormancy break (sprout initiation), sprout number and length varied depending on variety (tables 5 and 6). In general, decisions and actions on weather or not to store potatoes and how to store them must depend up on circumstances of individual cases. Therefore, the choice or recommendation of a given method should better be made using research information and knowledge on the influence of storage variables on the quality of the stored potatoes and on storage losses in the desired storage time. 
Table 5. Performance of improved potato cultivars after storage for 216 days in diffused light store

\begin{tabular}{|l|c|c|c|c|}
\hline \multicolumn{1}{|c|}{ Variety } & $\begin{array}{c}\text { Time to sprout initiation } \\
\text { (days) }\end{array}$ & $\begin{array}{c}\text { No. of sprout per } \\
\text { tuber }\end{array}$ & $\begin{array}{c}\text { Sprout length } \\
(\mathbf{m m})\end{array}$ & $\begin{array}{c}\text { Tuber wt loss } \\
(\mathbf{\%})\end{array}$ \\
\hline Sissay & 39 & 5.2 & 10.04 & 25.3 \\
\hline AL- 624 & 16 & 8.0 & 9.9 & 32.5 \\
\hline Tolcha & 28 & 4.0 & 8.9 & 12.4 \\
\hline Wochecha & 38 & 5.0 & 7.4 & 33.1 \\
\hline Awash & 44 & 5.5 & 11.1 & 27.8 \\
\hline Menagesha & 25 & 4.0 & 6.3 & 19.0 \\
\hline Genet & 52 & 5.1 & 13.9 & 32.9 \\
\hline Local & 19 & 8.6 & 6.7 & 22.6 \\
\hline Mean & $\mathbf{3 2 . 6}$ & $\mathbf{5 . 6 8}$ & $\mathbf{9 . 3}$ & $\mathbf{2 5 . 7}$ \\
\hline
\end{tabular}

Table 6. Effect of storage days and tuber size on sprout growth in diffused light store, Holetta

\begin{tabular}{|c|c|c|c|c|}
\hline \multirow{2}{*}{ Days in storage } & \multicolumn{3}{|c|}{ Sprout growth (mm) } & \multirow{2}{*}{ Mean } \\
\cline { 2 - 4 } & $25-35$ & $35-50$ & $50-60$ & 10.3 \\
\hline 15 & 11.5 & 9.1 & 10.3 & 22.4 \\
\hline 30 & 15 & 24.7 & 27.6 & 30 \\
\hline 45 & 19.7 & 31.8 & 38.5 & 61.3 \\
\hline 60 & 48.5 & 64.7 & 70.6 & 46.9 \\
\hline 75 & 36.1 & 46.3 & 58.3 & 52.2 \\
\hline 105 & 40.1 & 55.8 & 60.8 & 90.8 \\
\hline 120 & 70.9 & 88.4 & 113 & 90.8 \\
\hline Mean & 75.0 & 104.1 & 93.5 & \\
\hline
\end{tabular}

\section{Ware potato storages}

Postponed harvesting is the most commonly used storage method for ware potatoes in the highland and northwestern areas of the country to extend piece-meal consumption and also to wait for a better price (Endale et al., 2008). According to these authors, tubers can be kept up to 4 months without major quality loss in cool highlands. This storage method is also used to store seed potatoes. The effect of sun and radiant heat on the storage interior should be avoided by including resistance to these effects so that the desired cool condition is maintained. This is because consumption potatoes (ware potatoes) must be kept in dark to prevent greening of tubers. The high water content and rich carbohydrate is conducive for spoilage through respiration and pathogen attack. Therefore, the inside temperature is maintained at low level. All specialized stores or storage structures should have a roof space of not less than $1 \mathrm{~m}$ wide to shade walls from high hot sun. Buildings should be placed, if possible, with the long axis east to west. This can be modified by the need to place a long side across the prevailing night wind so as to allow natural ventilation.

Table 7. Percentage tuber weight loss of different potato varieties in naturally ventilated store at two different seasons

\begin{tabular}{lcc}
\hline \multirow{2}{*}{ Variety } & \multicolumn{2}{c}{ Weight loss (\%) } \\
\cline { 2 - 3 } Jalenie & Nov.-Feb. storage & Jun-Sept storage \\
Wechecha & 12.5 & 10 \\
Digemegn & 15 & 12.5 \\
Tolcha & 10 & 5 \\
Zengena & 12.5 & 10 \\
Guassa & 15 & 12.5 \\
Menagesha & 12.5 & 10 \\
Gorebella & 17.5 & 15 \\
\hline Mean & 15 & 10 \\
\hline
\end{tabular}

The above describe naturally ventilated ware potato storage has two compartments. Potatoes are stacked at the height not exceeding $1.5 \mathrm{~m}$. The wall is made up of mud with a thickness of not less than $10 \mathrm{~cm}$. To avoid crack formation, the mud must be well fermented and stabilized with straw. Following the night wind direction, the stores are constructed with air inlet and outlet openings. These are opened during the night from sunset to sunrise to allow air circulation, exhausting the day's heat due to respiration of the stacked potatoes and cooling it with the lower night temperature. The roof slope in one direction and covered with straw.

Matured potatoes are much more desirable for home consumption as well as processing than less matured ones. Therefore, ware potato should be harvested at full maturity stage when the soil is slightly moist to prevent 
tuber abrasion and to avoid tuber damage. All potatoes showing greening, any decay or damage are rejected for storage. Tubers showing disease symptom and any other mechanical damage are unfit for storage; therefore, such tubers are carefully separated and avoided. The harvested potatoes must be cured to repair any skin injuries and to promote the formation of stronger epidermis to reduce water loss. Good quality potato tubers, that are suitable for storage can then be kept and stored. Evaluation of ware quality of potatoes stored in locally made household level naturally ventilated ware potato storage with $2 \mathrm{~m} \mathrm{x} 1.5 \mathrm{~m}$ x $2 \mathrm{~m}$ size was made for eight potato varieties with stack height $(1.5 \mathrm{~m})$ recommended for naturally ventilated ware potato stores at Holetta. The walls were made up of mud having a thickness of not less than $10 \mathrm{~cm}$ and roofed with grass to protect temperature build-up and direct sunlight. The cool night wind of the highland is employed using an air inlet and outlet openings which remained opened at night (from sun set to sun rise) to avoid the entrance of hot air into the stored potatoes.

The result (Table 7) showed that potatoes from both main and off-season production could be stored for about four months (120 days) with losses ranging 5-17.5\% depending on the potato variety and the internal and external storage temperature and relative humidity. At Holetta, with temperatures and relative humidity presented in (Table 8), potatoes could be stored for four months. Variety Digemegn had got the minimum and Menagesha the maximum storage weight losses (Table 9). The other potatoes varieties showed storage weight losses between 10$15 \%$. Potato produced in the off-season and stored from May to August showed the lowest storage weight loss. The evaluation included quality changes in terms of tuber firmness, emaciations, crisp quality and sprouting from storage sample every 15 days. The results related to processing and utilization are discussed in the following section.

Table 8. Environmental conditions of naturally ventilated stores for ware potato stored for 120 days at Holetta

\begin{tabular}{|c|c|c|c|c|}
\hline \multirow{3}{*}{$\begin{array}{l}\text { Environmental } \\
\text { factor }\end{array}$} & \multicolumn{4}{|c|}{ Storage period } \\
\hline & \multicolumn{2}{|c|}{$\begin{array}{c}\text { Main-season harvest } \\
\text { (Nov -Feb) }\end{array}$} & \multicolumn{2}{|c|}{$\begin{array}{l}\text { Off-season harvest } \\
\text { (Jun-Sept) }\end{array}$} \\
\hline & Internal & External & Internal & External \\
\hline Temperature $\left({ }^{0} \mathrm{C}\right)$ & 3.6 & 22.7 & 7.83 & 19.84 \\
\hline RH (\%) & 86.6 & 53.8 & 87.09 & 75.81 \\
\hline
\end{tabular}

Table 9. Mean tuber weight loss of four cultivars in naturally ventilated ware storage at Holetta

\begin{tabular}{lll}
\hline Treatments (days in ground after $\mathbf{1}^{\text {st }}$ harvest) & $\begin{array}{l}\text { Mean fresh weight } \\
\text { loss } \mathbf{( g / k g )}\end{array}$ & \begin{tabular}{l}
$\%$ loss on fresh weight bases \\
\hline 30
\end{tabular} \\
60 & 33.5 & 3.35 \\
90 & 133.25 & 13.32 \\
120 & 183.5 & 18.35 \\
\hline
\end{tabular}

\section{Processing and Utilization}

In Ethiopia most of the potato produced is consumed as boiled potato and frequently prepared in local dishes sauced or mixed with other vegetables and spices. The per capital consumption of potato in Ethiopia is probably the lowest in Africa (Solomon, 1987 and Workafes, 2006). The main reasons for the low consumption of potato are poor post-harvest handling and supply, unavailability of processing industries, lack of improved varieties with appropriate processing quality (chips, crisps, dehydrated potatoes and several potato-based snack food products), and lack of awareness of the different uses of the crop (Sapers, 2003).

In recent years, the demand for potato chips and crisps is increasing very rapidly in urban areas. However, the focus of the variety improvement in the last two decades was more on improving productivity. Therefore, evaluation of existing potato varieties for their processing quality like chips and crisps has since recently been an important exercise. Although the overall tendency to the processing qualities of potato is a heritable varietal character, it is also influenced by storage environment such as period of storage (Fallik and Aharoni, 2004). Quality assessment of released potato varieties for crisps, chips, dry matter content, and specific gravity was made to study seasonal and varietal effects.

The results of the study showed that potatoes produced in the off-season had higher dry matter content and specific gravity than from the main season potatoes for most of the varieties (Table 11). In the main season, variety Digemegn followed by Jalenie, Zengena and Tolcha had the highest dry matter and specific gravity. In the offseason production, variety Digemegn, Jalenie and Tolcha showed the highest dry matter content, 25.5\%, 24.7\% and $23.97 \%$, respectively. Both in the main and off-season production variety Digemegn gave the highest dry matter content and specific gravity, while Menagesha had the lowest (Table 11). The result indicated that even if there was a difference among varieties and seasons, except for Menagesha, stored potatoes from main and offseason production had acceptable dry matter and specific gravity for processing.

The specific gravity of the tubers was calculated using the formula: 


\section{Specific gravity $=\underline{\text { Weight in air } \times 100}$}

(Weight in air - weight in water)

Table 11. Seasonal and varietal effects on dry matter and specific gravity for varieties improved

\begin{tabular}{lllllll}
\hline & Main season & \multicolumn{3}{c}{ Off-season } & Over seasons \\
\cline { 2 - 6 } Variety & $\begin{array}{l}\text { Dry matter } \\
(\%)\end{array}$ & $\begin{array}{l}\text { Specific } \\
\text { gravity }\end{array}$ & $\begin{array}{l}\text { Dry matter } \\
(\%)\end{array}$ & $\begin{array}{l}\text { Specific } \\
\text { gravity }\end{array}$ & $\begin{array}{l}\text { Dry matter } \\
(\%)\end{array}$ & $\begin{array}{l}\text { Specific } \\
\text { gravity }\end{array}$ \\
\hline Digemegn & 24.93 & 1.105 & 25.49 & 1.107 & 25.21 & 1.113 \\
Zengena & 23.08 & 1.098 & 23.52 & 1.098 & 23.30 & 1.097 \\
Jalenie & 23.29 & 1.096 & 24.72 & 1.103 & 24.01 & 1.099 \\
Gorebella & 22.43 & 1.093 & 22.36 & 1.093 & 22.40 & 1.093 \\
Guassa & 22.07 & 1.091 & 22.85 & 1.095 & 22.46 & 1.093 \\
Menagesha & 18.87 & 1.078 & 18.97 & 1.075 & 18.72 & 1.076 \\
Tolcha & 22.95 & 1.096 & 23.97 & 1.097 & 23.45 & 1.098 \\
Wechecha & 22.91 & 1.094 & 23.44 & 1.097 & 23.18 & 1.096 \\
& 22.57 & 1.094 & 23.17 & 1.096 & 22.84 & 1.096 \\
S.e. & 0.602 & 0.002 & 0.467 & 0.002 & 0.380 & \\
\hline
\end{tabular}

Potatoes with a dry matter content of $20-24 \%$ are ideal for making French fries, while those with a dry matter of up to $24 \%$ are ideal for preparing crisps. Moreover, good quality potatoes should have a specific gravity value of more than 1.080. Potato tubers with specific gravity values of less than 1.070 are generally unacceptable for processing (kabira and Berga, 2003). Potatoes stored at relative humidity of $83-84 \%$ increase in specific gravity during storage at both $4.4{ }^{\circ} \mathrm{C}$ and $12.8{ }^{\circ} \mathrm{C}$. At $90 \%$ relative humidity, the specific gravity of tubers remained unchanged in storage to 6 and half months at $4.4{ }^{\circ} \mathrm{C}$ and $10{ }^{\circ} \mathrm{C}(\mathrm{Smith}, 1987)$. Trained panellist evaluation was also made for quality of chips and crisps using characters colour, flavour, color, flavor, texture and overall acceptability. The results indicated that in main season production variety Jalenie followed by Tolcha, Zengena, Guassa and Wechecha were highly preferred for their crisping; but all varieties had acceptable quality (Table 12). For chips in the main season production, the most preferred potato variety was Jalenie, followed by Zengena, Guassa and Tolcha. Jalenie from both main and off-season production had the most preferred crisps and chips. As noted above, Jalenie was also the second, next to Digemegn, in its dry matter content and specific gravity both in the main and off-season production. Varieties Tolcha, Zengena, Guassa and Wechecha were equally preferred for their crisping quality. Variety Digemegn, although it had the highest dry matter and specific gravity, was not preferred as much as Jalenie.

Table 12. Trained panelist evaluation of chips and crisps quality of potatoes after 120 days in naturally ventilated storage

\begin{tabular}{llllllc}
\hline & \multicolumn{9}{c}{ Evaluation (Score on 1-9 scale)* } & \multicolumn{2}{c}{ Over seasons } \\
\cline { 2 - 7 } Varieties & \multicolumn{2}{c}{ Main season } & \multicolumn{2}{c}{ Off season } & \multicolumn{2}{c}{ Chisps } \\
\hline Jalenie & 6.9 & 6.3 & 7.2 & 6.7 & 7.0 & 6.5 \\
Wechecha & 6.6 & 5.9 & 6.5 & 6.2 & 6.5 & 6.1 \\
Tolcha & 6.6 & 6.2 & 6.8 & 6.7 & 6.7 & 6.5 \\
Zengena & 6.6 & 6.2 & 6.7 & 6.4 & 6.6 & 6.3 \\
Guassa & 6.6 & 6.2 & 6.6 & 6.4 & 6.6 & 6.2 \\
Gorebella & 5.9 & 5.9 & 6.2 & 5.8 & 6.1 & 5.6 \\
Menagesha & 5.5 & 5.8 & 6.2 & 5.8 & 5.9 & 5.8 \\
Digemegn & 4.5 & 4.2 & 5.6 & 4.6 & 5.0 & 4.5 \\
s.e. & 0.367 & 0.404 & 0.302 & 0.321 & 0.239 & 0.253 \\
\hline
\end{tabular}

*Scores on 1-9 scale with extreme values of like or dislike

\section{Summary and Conclusion}

In addition to raw consumption, potatoes can be processed into several products like chips, French fries, and canned products. The primary determinants for potato processing include high dry matter and low reducing sugar content. A dry matter content of more than 20 per cent is desirable for chips, French fries and dehydrated products. Similarly, reducing sugar content in tubers up to $100 \mathrm{mg} / 100 \mathrm{~g}$ fresh weight is considered acceptable for processing. This study indicates postharvest loss of $20-25 \%$ which is one of the major problems in the potato production. Among potato varieties studied for processing quality Jalenie is the most preferred variety for both chips and crips processing during the main and off-season potato production. Except Digemegn all the rest potato varieties included in this experiment are acceptable for potato chips and crisps. Thus from this experimental result the most 
suitable potato varieties for potato crisps and chips processing are Jalene, Tolcha, Zengena and Guassa. Moreover, these varieties can be stored more than three months in ware potato storage with minimal weight loss without losing their suitability for chips and crips processing.

\section{References}

Benyam Tadesse, Fayera Bakala and Lamirot W. Mariam, 2018. Assessment of postharvest loss along potato value chain: the case of Sheka Zone, southwest Ethiopia. Agric and Food Secur. 7:18

Borgel H., 1980. Production, Marketing and Consumption of Potatoes in the Ethiopian Highlands (Holetta, Awassa and Alemaya). Centre for Advanced Training in Agricultural Development, Institute of Socio-Economics of Agricultural Development, Technical University of Berlin. 1980.

Bradeen, J.M., and K.G. Haynes. 2011. Introduction to potato. In Genetics, genomics and breeding of potato, ed. JM Bradeen and C. Kole, 1-19. CRC Press.

Buys, E.M. and Nortje, G.L., 1997. 'Horticultural Crops Post harvest handling, Food Industries of South Africa, October Issue.

B.W.Watts.andG.L. Ylimaki and et.al.,1989. Basic Sensory method for food evaluation: Ottawa, Canada.

Clark, D., Klee, H. and Dandekar, A., 2004. 'Despite benefits, commercialization of horticultural crops ', Californian Agriculture, Vol. 58, No. 2, pp.89-98.

Crissman, C.C. Mc Arthur Crissman and Carli C., 1993. Seed Potato Systems in Kenya, A case study.Lima, International Potato Center, pp:44.

Crisosto, C.H. and Crisosto, G.M., 2001.'Understanding consumer acceptance Postharvest Biology and Technology, Vol. 22, pp.205-213.

CSA (Central statistical agency), 2015/16. Agricultural sample survey, report on area, production and farm management practice of belg season crops for private peasant holdings. Volume V, Statistical Bulletin 578. Addis Ababa, Ethiopia.

Devaux A., P. Kromann, and O. Ortiz., 2014. Potatoes for sustainable global food security. Potato Research 57 (3-4): 185-199. ISSN 0014-3065.DOI 10.1007/s11540-014-9265-1.

Elazar, R., 2004. Marketing: International Research and Development Course on Postharvest Biology and Technology. The Volcani Center, Israel.

Endale, G., Gebremedhin, W., Bekele, K., Lemaga, B., 2008. Post harvest management. In: Root and tuber crops: The untapped resources, eds W. Gebremedhin, G. Endale, Lemaga, B. 113-130. Addis Ababa, Ethiopia: Ethiopian Institute of Agricultural Research.

Fallik, E. and Aharoni, Y. 2004. Postharvest Physiology, Pathology and Handling of Fresh Produce. Lecture Notes. International Research and Development course on Postharvest Biology and Technology. The Volcani Center, Israel. 30pp.

FAO, 2013. Ethiopia: Country fact sheet. Accessed 25 February 2013 and available at http:// www. fao.org/nr/water/aquastat/data/factsheets/aquastat_fact_sheet_eth_en.pdf.

Gebremedhin Woldegiorgis. 2013. Potato variety development strategies and methodologies in Ethiopia. In: Gebremedhin Woldegiorgis, Staffen Schulz and Baye Berihun (eds.). pp. 45- 59. Seed potato tuber production and disseminations, experiences, challenges and prospects. EIAR and ARARI, 12-14 Mach 2012, Bahir Dar, Ethiopia.

Gebremedhin, W/Giorgis, Endale, G., Kiflu, B. and Bekele, K., 2001. Country Profile on Potato Production and Utilization: Ethiopian Agricultural Research Organization (EARO), Holetta Agricultural Research Centre, National Potato Research Program, Ethiopia.

Gildemacher, P., W. Kaguongo, O. Ortiz, A. Tesfaye, W. Gebremedhin, W.W. Wagoire, R. Kakuhenzire, P. Kinyae, M. Nyongesa, P.C. Struik, and Leewis C., 2009a. Improving potato production in Kenya, Uganda and Ethiopia. Potato Research.

Gildemacher, P., Demo, P., Barker, I., Kaguongo, W., Gebremedhin, W., Wagoire W.W., Wakahiu, M., Leeuwis, C., Struik P.C., 2009b. A description of seed potato systems in Kenya, Uganda and Ethiopia. American Journal of Potato Research 86:373-382.

Hickson, B. 2004. Quality Standards for Fresh Fruit and Vegetables. Power Point Lecture Slides. International Research and Development course on Postharvest Biology and Technology. The Volcani Center, Israel.

Hirpa, A., Meuwissen, M.P.M., Tesfaye, A., Lommen, W.J.M., Oude Lansink, A.G.J.M., Tsegaye, A. and Struik, P.C., 2010. Analysis of Seed Potato Systems in Ethiopia. American Journal of Potato Research 87, 537-552.

Kabira, J. N and Berga L., 2003. Potato processing, Quality evaluation procedure for research and food industry in east and central Africa. Nairobi, Kenya.

Kantor, L.S., Lipton, K., Manchester, A., and Oliveira, V. 1997. Estimating and addressing America's food losses. Food Review 20:3-11.

Lemaga, B., Hailemariam, G., Gebremedhin, W., 1994. Prospects of seed potato production in Ethiopia. In: Proceedings of the Second National Horticultural Workshop of Ethiopia, eds E. Hareth and D. Lemma, 254- 
275. Addis Ababa, Ethiopia: Institute of Agricultural Research and FAO.

Lung'aho, C., Lemaga, B., Nyongesa, M., Gildermacher, P., Kinyale, P., Demo P., and Kabira, J. 2007. Commercial seed potato production in eastern and central Africa. Kenya agricultural research institute. 140 pp.

Mulatu, E., Osman E. I., Etenesh, B., 2005a. Improving potato seed tuber quality and producers' livelihoods in Hararghe, Eastern Ethiopia. Journal of New Seeds 7(3):31-56.

Mulatu, E., Osman, E. I., Etensh, B., 2005b. Policy challenges to improve vegetable production and seed supply in Hararghe, Eastern Ethiopia. Journal of Vegetable Science 11(2):81-106.

Pankhurst, R.1964. Notes on a history of Ethipian Agriculture. Ethiopian Observer. 7:210-240.

Sapers, G.M. 2003. 'Washing and sanitizing raw materials for minimally processed fruit and vegetable products', in J.S. Novak, G.M. Sapers and V.K. Juneja (Eds.) Microbial Safety of Minimally Processed Foods, FL: CRC Press, pp.221-253.

Smith, O., 1987. Potatoes: production, storing and processing. $2^{\text {nd }}$ edition. The AVI publishing company, Westport, Connecticut, USA.

Solomon Yilma, 1987. Review of Potato Research in Ethiopia. In: Godfrey-SamAggrey,W and Breke Tsehai Tuku (eds.). Proceedings of first Ethiopian horticultural workshop. 20-22 February.1985.Addis Ababa, Ethiopia.

Tesfaye, A. Lemaga, B. Mwakasendo, J. A. Nzohabonayoz, Z., Mutware, J., Wanda, K.Y., Kinyae, P. M., Ortiz, O., Crissman, C., Thiele, G., 2010. Markets for fresh and frozen potato chips in the ASARECA region and the potential for regional trade: Ethiopia, Tanzania, Rwanda, Kenya, Burundi and Uganda. International Potato Center (CIP), Lima, Peru. Working Paper, $44 \mathrm{p}$.

William F. Talburt and Ora Smith, 1987. Potato processing. Van Nostrand Reinhold Company Inc. Newyork. 